\title{
Foreign Direct Investment in Agriculture in Zambia has it Brought Tangible Economic Results
}

\author{
Article by Bridget Ngonga \\ Management, Texila American University \\ E-mail: lungonga@gmail.com
}

\begin{abstract}
Foreign Direct Investment (FDI) involves movement of resources from foreign countries into the local economy. Foreign Direct Investment is the key driver of economic growth in many developing countries in the world. Despite Foreign Direct Investment being a key driver of economic growth, Foreign Direct Investment in Agriculture in Zambia has not stimulated great economic growth despite the country having vast arable land and a lot of water bodies lying across the country.

The study covers Foreign Direct Investment in agriculture in Zambia which includes; size and growth of the economy, physical, financial and technological infrastructure and investment promotions. It also addresses the role of Foreign Direct Investment in the agricultural sector which is job creation. An analysis of the policy frame in agriculture was carried to show how Foreign Direct Investment in agriculture is supported. The paper also outlines challenges and limitations that affect growth of Foreign Direct Investment in agriculture in Zambia. These include; poor road network, poor land policy in agriculture, political risks, poor economic environment in the country and high corruption rate. Activities undertaken by government in improving agriculture in the country has also been analyzed in this paper, such as provision of incentives to investors in agriculture, crop diversification, and introduction of Farm blocks in the various parts of the country

This study will contribute to Foreign Direct Investments in stimulating economic growth and improvement in developing Countries. Foreign investment inflows in Agriculture also saw a rise in the number of accommodation establishments and employment levels.
\end{abstract}

Keywords: Zambia, Foreign Direct Investment, Economic Growth, Agriculture, Employment.

\section{Introduction}

Zambia is a land locked country with a lot of potential in the agriculture sector. Zambia economy highly relies on the mining sector but if the agriculture sector is developed it can contribute to the economic growth of the country.

The Agriculture sector potential can be seen in by the available market such as the neighboring countries that are experiencing drought and food shortages while Zambia has had enough rain for rain harvesting and crop production. Over 60 percent of the population derives its livelihood from agriculture. (Ministry of Agriculture Report, 2007) Therefore, the trend from other studies shows that Foreign Direct Investment can be essential source of private capital for developing economies especially in countries with friendly environment (Recent trends show that Foreign Direct Investment can be an important and stable source of private capita (Jun and Singh, 1996). This sector is not highly developed due to reason such as

1. Limited financing. This can be attributed to high interest rates by the banks.

2. High reliance on rain feed crops.

3. Lack of information of new technologies.

4. Power cuts due to load shedding.

5. Limited crop production Zambia main crop production is Maize.

The list is endless. The Agriculture industry in Zambia consists mostly of small-scale farmers. For this sector to develop there is need to attract Foreign Direct Investment. The rate of investments in agriculture is important because it increases the stock of capital used to produce food and fiber. As the role of Foreign Direct Investment can thus be seen as to exploit the home country's comparative 
advantages in intermediate inputs that are embodied in products whose final stages of production give a comparative advantage to the host country (Dunning, 1993a).

However, Foreign Direct Investments is foreign capital investment to a country. Foreign direct investment to a country results in increasing productivity, reducing unemployment, and increasing the use of technology. The need for Foreign Direct Investments came as a result of shortages in domestic funding sources to finance development projects in developing countries.

However, according to Khalfan (2002), the Direct Investment theory states that increased Foreign Direct Investment flows from industrialised countries to less industrialized countries is as a result of the positive rates of return that accrued from capital utilization in less industrialized countries. Zambia in this case can be considered as a favourable destination for foreign investments as it provided investors with possible gains from its predominantly labour-intensive economy.

\section{Methods}

Both primary and secondary data were obtained for the purpose of achieving the objectives that were set for the study. In utilising the quantitative data, tabular and graphical representations were used to determine the benefits accruing from agricultural activities and incentives

The data collected is analysed in the statistical analysis provided below through charts and various diagrams below.

\section{Results and discussions}

\section{Role of foreign direct investment in the agricultural sector}

Foreign Direct Investment in the agricultural sector is important for growth and development for the Zambian economy. It drives business reform, policy formulation and reforms, and creates employment. Foreign Direct Investment in the agricultural sector in Zambia have facilitated technology transfer, increased export earnings, and increased business opportunities for local businesses who are able to transact with these Foreign Investors, employment generation, increased incomes, and increased government revenue (through taxation, commissions, licenses and permit fees), all of which are critical in reducing poverty. Some of the contributions of Foreign Direct Investment in the agricultural in Zambia are highlighted below:

\section{Foreign investment's contribution to employment}

Surveys are conducted yearly by Government mandated institutions to collect information on employment by Majority - Owned Foreign Affiliates operating in Zambia so as to assess their contribution to employment in the country. The surveys from 2010 to 2014 established the following details as highlighted in table 1 below:

Table 1. Employment levels by FDIS in the agricultural sector, 2010 - 2014

\begin{tabular}{|l|l|l|l|l|l|}
\hline & $\mathbf{2 0 1 0}$ & $\mathbf{2 0 1 1}$ & $\mathbf{2 0 1 2}$ & $\mathbf{2 0 1 3}$ & $\mathbf{2 0 1 4}$ \\
\hline $\begin{array}{l}\text { Number of Jobs } \\
\text { Created }\end{array}$ & 2,441 & 3,471 & 3,647 & 5,272 & 5,725 \\
\hline
\end{tabular}

Source: Foreign Private Investment \& Investor Perceptions Surveys, 2011,2012,2013,2014 and 2015

The survey established that the level of employment created by Majority-Owned Foreign Affiliates in all the sectors stood at 56,700 in 2010. With the agricultural sector contributing 2,441 jobs. Figure 1below provides a sectarian analysis of employment created in 2010. 


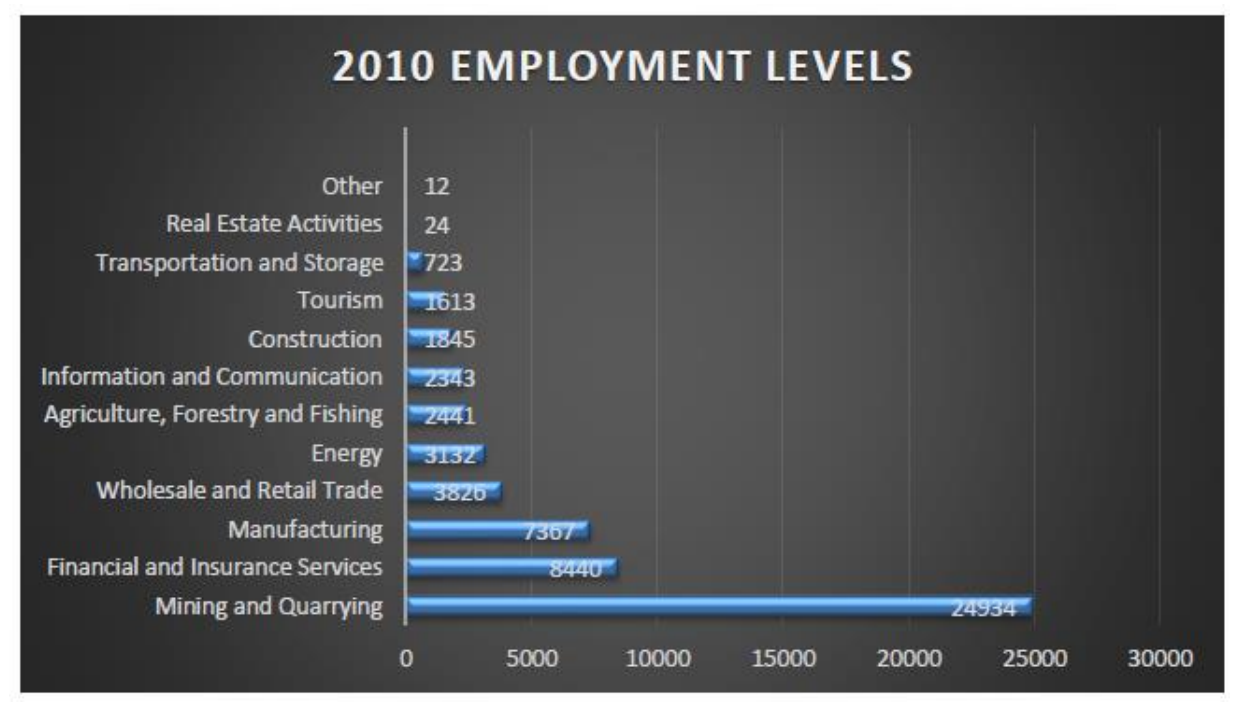

Figure 1. Employment levels of majority-owned foreign affiliates by sector, 2010

Source: Foreign Private Investment \& Investor Perceptions Survey, 2011

In 2011 the level of employment created by Majority-Owned Foreign Affiliates in all the Sectors stood at 66,778 . The agricultural sectors contributed 3,471 employees (5.20 percent).

A sector analysis of employment created in 2011 is summarized in figure 2 below

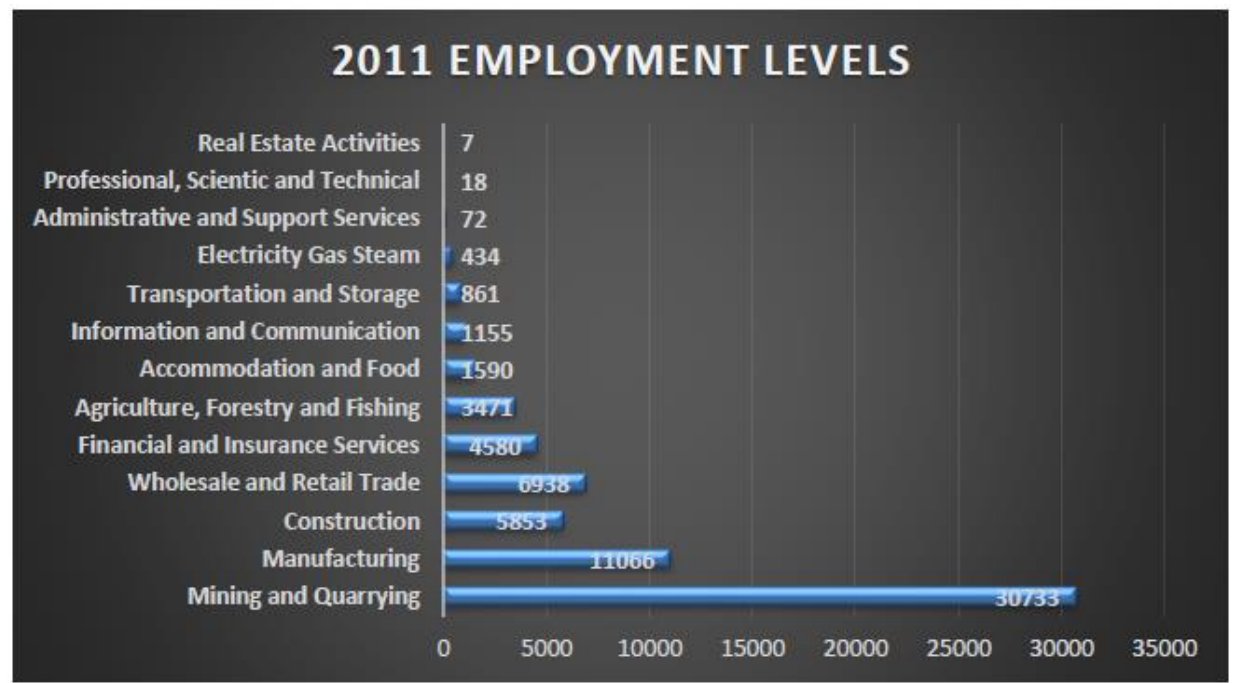

Figure 2. Employment levels of majority-owned foreign affiliates by sector, 2011

Source: Foreign private investment \& investor perceptions survey, 2013

For 2012, overall employment created by MOFAs stood at 70,653 with the agricultural sector contributing 3,647 jobs (5.16\%). Figure 3 below provides a sector analysis of the jobs created in all the sectors. 


\section{EMPLOYMENT LEVELS}

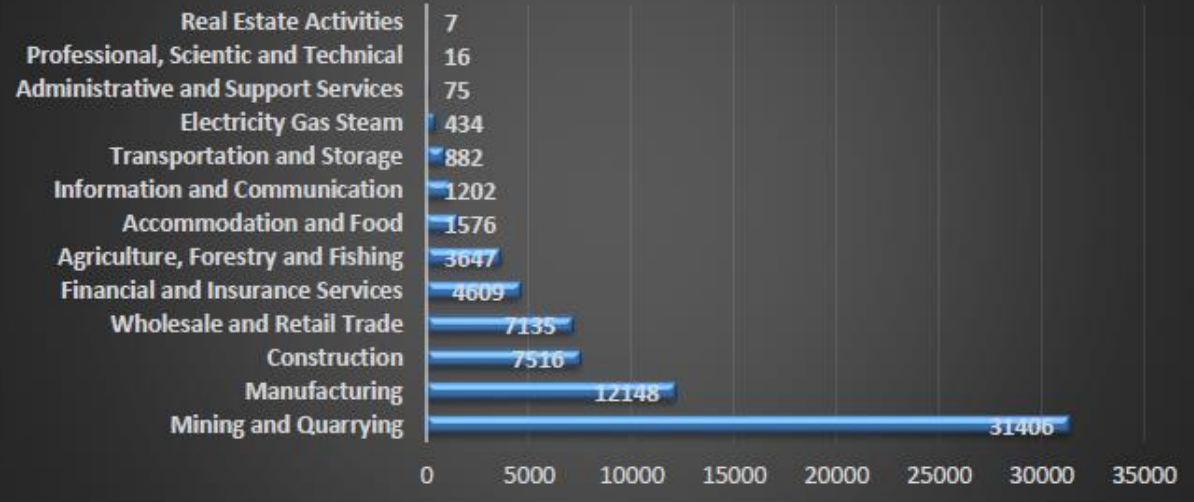

Figure 3. Employment levels of majority-owned foreign affiliates by sector, 2012

Source: Foreign Private Investment \& Investor Perceptions Survey, 2013

With regard to 2013, the survey findings showed that the agricultural sector contributed 5,272 (6.72\%) jobs to the 78,475 jobs created by Majority-Owned Foreign Affiliates. A sector analysis is provided in figure 4 below.

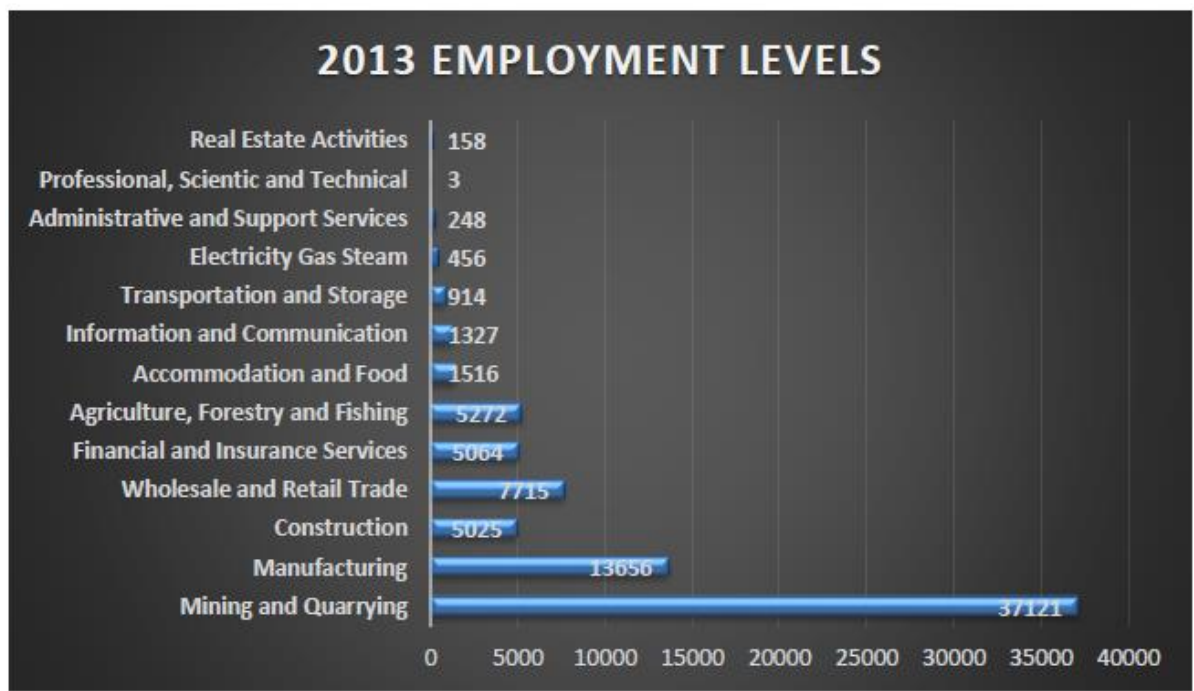

Figure 4: Employment levels of majority- owned foreign affiliates by sector, 2013

Source: Foreign private investment \& investor perceptions survey, 2014

In 2014 Majority-Owned Foreign Affiliates accounted for 87,527 employees, with the agricultural sector contributing 5,725 jobs representing $7 \%$ of the total jobs created. In figure 4 below is a sector by sector analysis of the jobs contribution. 


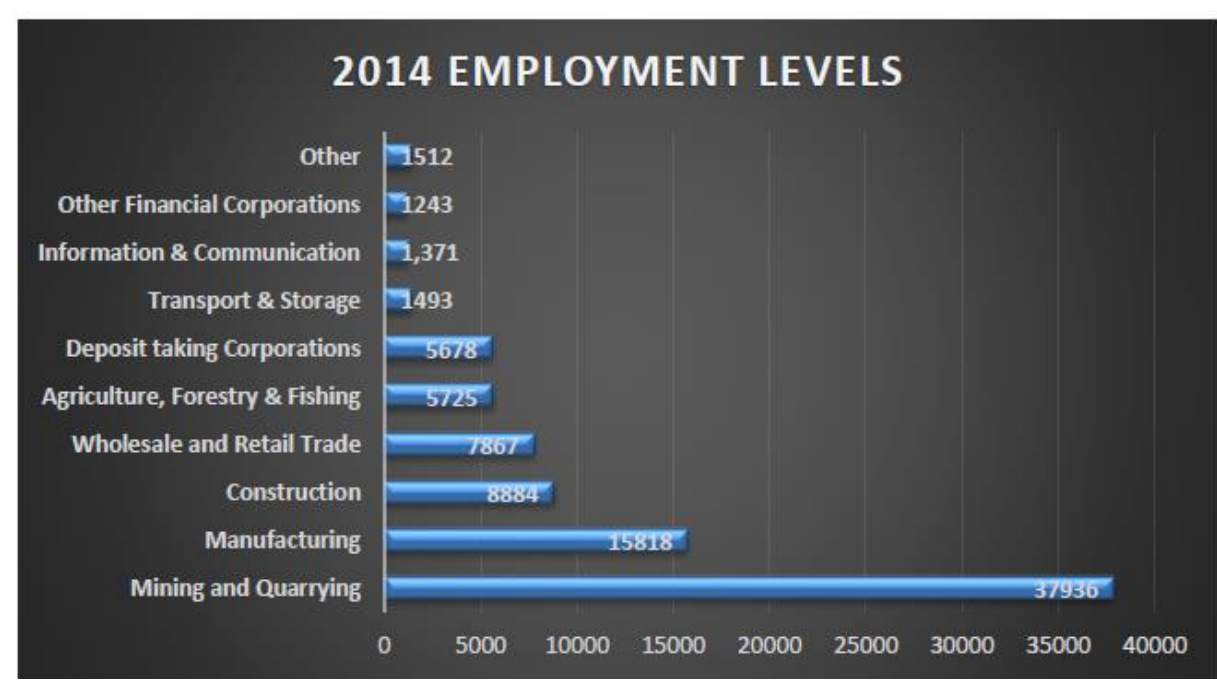

Figure 5. Employment levels of majority-owned foreign affiliates by sector, 2014

Source: Foreign private investment \& investor perceptions survey, 2015

\section{Other contributions}

Foreign Direct Investments in the agricultural sector also contribute significantly to the Zambian economy through the payment of taxes (corporate tax) on income generated. For example, in 2012 Ministry of Finance As paid a total of US\$15million, US\$900,000 in 2013 and US\$2.4million in 2014 (Foreign Private Investment \& Investor Perception Surveys, 2013, 2014 and 2015).

Foreign Direct Investments also provide business opportunities to the local companies which are able to supply goods, works and services to these investors. In addition, Foreign Direct Investments also facilitate technology transfer as some of the technologies that are used in the agriculture sector are new to Zambia and very advanced. Therefore, Foreign Direct Investments facilitate technology transfer. Research by Thomas (2007) on the U.S. federal government found that investment incentives were considered to be an opportunity to attract investment into the United States of America (U.S.). An incentive was focussed towards machinery and equipment depreciation, and it was estimated to have cost of US\$ 44.7 billion in economic year 2004. The author also found that in Canada, incentive initiatives were being used at the provincial level and that they were much more highly centralised. Huge incentives such as those in the automobile industry attracted federal as well as provincial participation in the awarding of subsidies

\section{Policy frame works in agriculture that promotes the growth of foreign Direct investment in agriculture}

According to Asiedu (2006), research showed that government policies are significant influencing Foreign Direct Investment flows into specifically to Governments can offer incentives to potential Foreign investors in the form of tax holidays, tax rebates, and investments in infrastructure among others. Policies that aim to train and upgrade the skills of the labour force are encouraged as this Increases human capital. Therefore, it is important that Governments also work to ensure that there is more transparency in their economies. Bartels et. al. (2009), show that governments needs to improve on their regulatory environment, emphasizing on creating laws that encourage people to do business in an economy. However, the government of Zambia has in place a National Agriculture Policy (NAP). The National Agricultural policy was Formulated in 2004 and covered the period up to 2015. This is the policy that is currently in place. The National Agricultural policy (2004-2015) statement states that "the overall Agriculture Policy is to facilitate and support the development of a sustainable and competitive agricultural sector that assures food security at national and household levels and maximizes the sector's contribution to Gross Domestic Product (GDP)."

The National Agricultural Policy has the following specific priority objectives; 
1. To ensure national and household food security throughout the all-year round production and post-harvest management of adequate supplies of basic food stuffs at competitive costs.

2. To contribute to sustainable industrial development by providing locally produced agro-based raw materials.

3. To increase agricultural exports thereby enhancing the sector's Contribution to the National Balance of Payments.

4. To generate income and employment through increased agriculture production and productivity.

5. To ensure that the existing agricultural resource base is maintained and improved upon.

The current National Agricultural Policy is comprehensive as it addresses all the key areas in the Agricultural sector these are; Management of Crop Production, Management of the Livestock, Management of Fisheries, Land Management and Marketing Services. For example, section 3.1.1 deals with Crop Management, section 3.3 deals with Land Management, section 3.5 deals with Livestock Management, section 3.6 deals with Fisheries, section 3.8 deals with Agricultural Marketing, section 3.8.2 deals with Agricultural Credit and Finance and Risk Management is dealt in section 4. The policy framework identifies all the major stake holders in the agricultural sector who are key in ensuring success implementation of the policy. These are the Government, Co-operatives and the Non-Governmental Organizations such Zambia Nation Farmers Union It outlines the various strategies that have to be implemented in order for the policy to succeed. Each sub sector has strategies that are specific to the sector and there are interventions that have been suggested to ensure successful implementation of the policy.

Key policy areas that addresses Increase in Foreign Direct Investment: The National Agricultural Policy has in place strategies that will positively influence the inflow of FDI in the country. The key Ones are as flows.

\section{a. Facilitating provision of incentives for local and foreign agricultural investment}

Ministry of Agriculture has been lobbying the Ministry of Finance and National Planning and other stakeholders for budgetary provisions of incentives in agriculture such as tax breaks and agricultural import/export incentives. The Ministry would also play a role of a marketing agency in linking up Agricultural investors to the Zambia Investment Centre and help them in dissemination of information on investment opportunities and incentives. This is a key area where valuable information for investors interested in agriculture can be obtained.

This strategy has already been implemented as currently all agricultural products are zero rated as far as taxation is concerned. This cost saving would encourage investors to come and invest in the agricultural sector in the country.

According to Quazi (2007), who conducted the research to examine nine Latin American countries, found that Foreign Direct Investment inflows decreased when government policy changed lead to higher trade barriers such as higher taxes, restrictions on foreign investment, a more suppressive financial system, additional price controls, and wage controls. While, bilateral investment treaties which were being used in many developing countries were found to have a positive effect on inward Foreign Direct Investment flows.

\section{b. Facilitating Availability and Accessibility of Land for Agriculture and Development of Infrastructure in Potentially Productive Agricultural areas}

The Government recognizes the duality nature of agriculture in Zambia and the poor state of infrastructure especially in some of the potentially productive agricultural areas. Special measures including rehabilitation of feeder roads, bridges, storage sheds, dams, canals, dip tanks; on-farm storage and others are needed to help farmers in these areas.

New farm blocks would be opened up in each of the nine provinces and also provided with the necessary infrastructure such as feeder roads, bridges, storage shed, electrification, dams and canals so as to attract both local and foreign investment in agriculture. The Ministry would liaise with the Ministry of Lands to facilitate availability and accessibility of land for agricultural development.

The growth of the agricultural sector in the country relies to a great extent on this strategy. The government has greatly invested in the development of road network in the country. A Master Plan 
called "Link 8000" has been formulated under the reforms in the road sector. A specific quasi government department called Road Development Agency (RDA) has been formed and is spear heading these reforms that have seen development of road in remote areas hence opening up the under developed rural areas for agricultural purposes.

The government has opened up Farm Blocks in all the 10 provinces by acquiring land from the traditional leaders and making available to investors in the agriculture sector.

Below is the diagram showing the various farm blocks in the country;

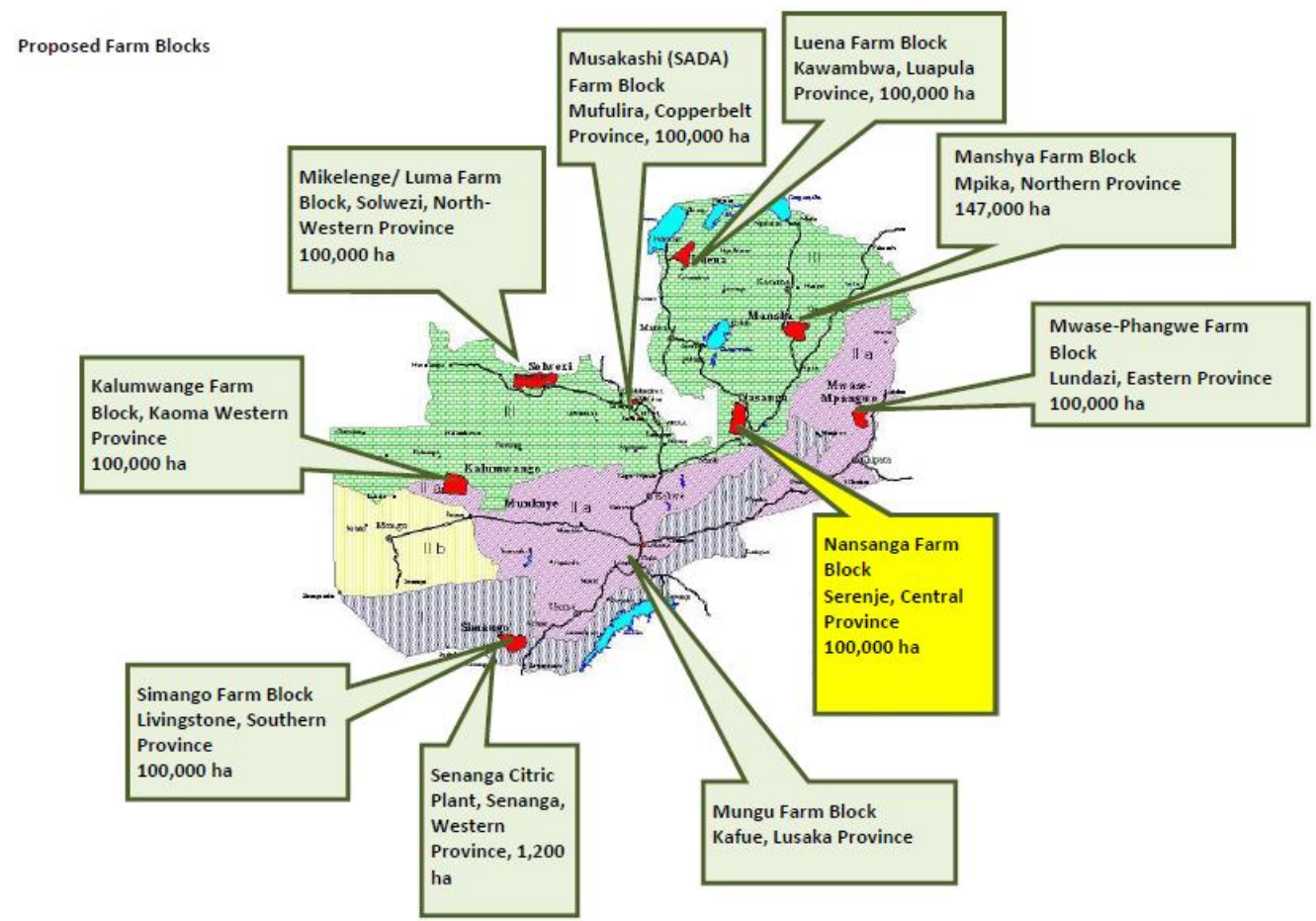

The current national agricultural policy has areas that various stakeholders in the country have identified needs urgent attention. There are some pieces of legislation current in force that needs to be reviewed so as to create a conducive environment for investors and other various stakeholders. The ones which are critical which will need immediate attention are the following: the development of an Agricultural Marketing Act that will regulate market players in agricultural marketing; the review of the Agricultural Credit Act to provide for use of warehousing receipt system as collateral in obtaining loans; legislations regarding animal health, livestock development, dairy development, animal identification and traceability and veterinary and Para-veterinary professional which are necessary to guide the sector on the control and prevention of livestock diseases as well as regulate dairy and livestock production; and the Fisheries Policy and Fisheries Act.

Also, the following legislation needs review; Cotton Act, Cap. 227, the Tobacco Act, Cap. 237 and 238, the Noxious Weeds Act, Cap. 231, the Plant Pests and Diseases Act, Cap. 233, the Environmental Protection and Pollution Control Act, Cap 204, the Water.

Rights Act, Cap. 198, the Lands Act, Cap. 184 and the Agricultural Lands Act Cap 187.

The current National Agricultural Policy is very comprehensive and if successfully implemented the country would greatly benefit.

Nowadays according to LaII (2005) it is well accepted that both economic growth and development are highly dependent on improving not just the availability of capital, but also access to technological capabilities, infrastructure and resources. Therefore, in the process of embracing Foreign Direct Investment as a solution to the innumerable economic ills of development, it is important to understand the rationale and the costs associated with such a policy stance. Simply put, emphasis should not only be placed on attracting Foreign Direct Investment, but also on understanding how best to optimize the benefits for the host economy. 


\section{Limitation and Challenges of Foreign Direct Investment in Agriculture Sector in Zambia}

\section{Poor road network}

Foreign Direct Investment in Agriculture in Zambia faces challenges due to poor road infrastructure. Most of the arable Land in Zambia is in the outskirts of the cities. The road infrastructure to the places is very bad or do not exist. As a result, foreign investors who would like to venture in Agriculture find it difficult to come and invest in Zambia. For example, there is fertile land in Northern, Muchinga and Luapula provinces of Zambia with good rain fall pattern but due to poor road network there is no development that taken place.

\section{Poor land policy in the country}

The land ownership policy in Zambia gives more power to the Traditional leaders. Most of the land in the country is owned by traditional leaders. These view land as a sign of wealth and they do not easily allow investors to come and invest. There is need to review the land policy in the country so that more land is made available to potential investors.

\section{Poor weather conditions in the country}

Zambia has been experiencing poor rain fall patterns in some parts of the country which has affected agriculture. This has largely been experienced in the southern, eastern and part of the western provinces. Investment in agriculture by its nature requires good rainfall patterns. Using irrigation is very expensive and as such most investors who invest in agricultural will need to huge investment in irrigation equipment such as centre pivots and large dams to overcome this challenge

\section{High interest rates}

Investments in agriculture require large amounts of funds and returns are realized over a long period of time. Investors would normally have to borrow or obtain loans from banks. High interest rates affect growth of the agricultural sector. Currently the interest rate being changed by banks is at $40 \%$ in Zambia. This is too high for any investor to borrow and invest in the agricultural sector whose returns take long time to be realized.

\section{Lack of reliable power supply (electricity)}

The main source of energy in Zambia is through hydroelectricity. Generation of hydro- power depends on the rains. There has been low rain pattern in the county in the recent years leading to low water levels in the dams where power is generated. This has led to serious rationalization of power in the country. The agricultural sector has been seriously affected as it relies on power to carry out irrigations in the dry seasons. Investment in this sector of the economy has greatly reduced.

\section{Conclusion}

Based on the findings, the study reached the following set of conclusions:

Foreign Direct Investment in agriculture was increasingly recognized as an important factor in the economic development of Zambia. It helped in improving in employment levels in Zambia in the agriculture sector, through the establishment of farm blocks in the various parts of the country. It was also established that Foreign Direct investment in Agriculture facilitate technology transfer as foreign companies come to invest in Zambia, they bring new technologies. Investment incentives were found to be an adequate factor in promoting Foreign Direct Investment and had a positive effect in attracting FDI towards the agricultural sector in Zambia. This was supported by results from the secondary data review and the various surveys conducted by many government agencies as displayed by in the analysis above. Job and wealth creation remain a major development agenda for the Government. 


\section{References}

[1]. Asiedu, E. "Foreign direct investment in Africa: The role of natural resources, market size, government policy, institutions and political instability," The World Economy, 29 (1), (2006): 63-77.

[2]. Bartels, F. L., Sadiq N. A. and Suman L. "Foreign direct investment in Sub-Saharan Africa: Motivating factors and policy issues," Journal of African Business, 10.2, (2009): 141-162.

[3]. Jun, K. W., and Singh, H. "The determinants of foreign direct investment: new empirical evidence," Transatlantic Corporations, 5, (1996): 67-106.

[4]. Khalfan, M. H. "Productivity of Zanzibar Tourism under the Private Direct Investment," (PhD thesis submitted to University Putra Malaysia), (2002).

[5]. Lall, S. "FDI, AGOA and manufactured exports by a landlocked, least developed African economy," Journal of Development Studies, 41, (2005): 998-1022.

[6]. National Agricultural Policy (2004-2015). Zambia.

[7]. Organisation for Economic and Co-operation Development (2000), "Main Determinants and Impacts of Foreign Direct Investment on China's Economy", OECD Working Papers on International Investment, 2000/04, OECD.

[8]. Quazi, R. M. "Investment climate and foreign direct investment: a study of selected countries in Latin America," (2007).

[9]. Thomas, K. P. "Investment incentives: Growing use, uncertain benefits, uneven controls," University of Missouri-St. Louis, Prepared for the Global Subsidies Initiative (GSI) of the International Institute for Sustainable Development (IISD), Geneva, (2007).

[10]. Transparency International 2001 “Corruption Perception Index" Report. Zambia.

[11]. Vision 2030" A Prosperous Middle - Income Nation by 2030. Zambia.

[12]. Zambia Fifth National Development Plan, Ministry of Finance and National Planning, 2007 